\title{
A Genizah Fragment's Version of the Amoraic Statements in Bavli Eruvin 103a ${ }^{1}$
}

Una versión del fragmento de Genizah de las declaraciones amoraicas en Bavli Eruvin $103^{\mathrm{a}}$

\section{Uri Zur*}

Ariel University | Ariel, Israel

uriz@ariel.ac.il

\begin{abstract}
The Genizah fragment Cambridge U-L T-S F2 (2) 23, numbered C98948 in the Friedberg Jewish Manuscript Society, includes among other things the amoraic controversy between R. Eleazar and R. Jose son of R. Hanina, as well as the give and take between R. Safra and Abaye in Tractate Eruvin 103a. Some of the researchers are divided concerning the initial formation of the sugya. The controversy between $R$. Eleazar and R. Jose son of R. Hanina as presented in the fragment's version poses difficulties and interferes with the ordered understanding of the methods utilized by these amoraim to solve the contradiction between the Mishna in Eruvin and the Mishna in Pesahim. The purpose of the article is to present the difficulties in the fragment's version with regard to the abovementioned amoraic controversy and reach conclusions regarding the precise original version of the fragment. Thus too in the matter of the fragment's version of the give and take between R. Safra and Abaye, which differs from other versions. The purpose of the article is to examine the fragment's version of this give and take in comparison to other versions and reach conclusions regarding the clearest and most precise version compared to the other versions.
\end{abstract}

Keywords: Bavli. Eruvin. Genizah.

Resumen: El fragmento Genizah Cambridge UL TS F2 (2) 23, numerado C98948 en la Friedberg Jewish Manuscript Society, incluye entre otras cosas la controversia amoraica entre R. Eleazar y R. Jose hijo de R. Hanina, así como el dar y recibir entre R. Safra y Abaye en Tractate Eruvin 103a. Algunos de los investigadores están divididos con respecto a la formación inicial de la sugya. La controversia entre R. Eleazar y R. Jose, hijo de R. Hanina, tal como se presenta en la versión del fragmento, plantea dificultades e interfiere con la comprensión ordenada de los métodos utilizados por estos amoraim para resolver la contradicción entre el Mishna en Eruvin y el Mishna en Pesahim. . El propósito del artículo es presentar las dificultades en la versión del fragmento con respecto a la controversia amoraica antes mencionada y llegar a conclusiones con respecto a la versión original precisa del fragmento. Así también en lo que respecta a la versión del fragmento del toma y daca entre R. Safra y Abaye, que

\footnotetext{
${ }^{1}$ I would like to express my thanks to the Syndics of Cambridge University Library for their permission to use the reproduction of Cambridge U-L T-S F2 (2) 23.

* Professor in Ariel University, Israel 


\section{Arquivo Maaravi}

Revista Digital de Estudos Judaicos da UFMG

ISSN: 1982-3053

difiere de otras versiones. El propósito del artículo es examinar la versión del fragmento de este dar y recibir en comparación con otras versiones y llegar a conclusiones sobre la versión más clara y precisa en comparación con las otras versiones.

Palabras clave: Bavli. Eruvin. Genizah.

\section{The Text of the Printed Version (bEruvin 103b)(Vilna ed.)}

Mishnah. A wen may be removed in the Temple but not in the country. If [the operation, however, must be performed] with an instrument it is forbidden everywhere.

Gemara. Is not this inconsistent with the following: Carrying it, bringing it from without the permitted Sabbath limit and removing its wen do not supersede the Sabbath, and R. Eliezer ruled: They do not supersede it? - R. Eleazar and R. Jose son of R. Hanina gave different explanations. One Master explains that both rulings refer to a soft wen and yet there is no difficulty, since the former deals with removal by the hand while the latter deals with removal by means of an instrument. And the other Master explains that both rulings refer to removal with the hand, and yet there is no difficulty, since the latter refers to a soft wen while the former refers to a dry one. But according to him who explained that the former dealt with removal by the hand while the latter dealt with removal by means of an instrument, what was his reason for not explaining that the latter dealt with a soft wen and the former with a dry one? - He can answer you: A dry one may be removed even by means of an instrument. What is the reason? Because it merely crumbles away. And according to him who explained that the latter referred to a soft wen while the former referred to a dry one, what was his reason for not explaining that the former referred to removal by hand and the latter to an operation by means of an instrument? - He can answer you: Concerning an instrument we have explicitly learnt, if [the operation, however, must be performed] with an instrument it is forbidden everywhere. And the other? - The reason why the ruling was taught there is because it was desired to indicate the divergence of opinion between R. Eliezer and the Rabbis. And the other? - The ruling must be similar to that of 'carrying it' or 'bringing it from without the permitted Sabbath limit' which is only a Rabbinical restriction. And the other? - As regards 'carrying it' he is not in agreement with R. Nathan who holds that a living being carries its own self; and he regards ' bringing it from without the permitted Sabbath limit', he is in agreement with R. Akiba who holds that the laws relating to Sabbath limits are Pentateuchal.

R. Joseph raised an objection: R. Eliezer argued, May not this be inferred a minori ad majus? If slaughtering which is forbidden under the category of work supersedes the Sabbath, how much more so should these, which come only under the category of shebuth, supersede the Sabbath? - Rather, said R. Joseph, both deal with removal by 


\section{Arquivo Maaravi}

Revista Digital de Estudos Judaicos da UFMG

ISSN: 1982-3053

hand but a shebuth relating to the Temple within the Temple has been permitted whereas a shebuth relating to the Temple in the country has not been permitted.

Abaye once sat at his studies and discoursed on this statement when R. Safra pointed out to him the following objection: If a man was reading in a scroll on a threshold and the scroll rolled out of his hand, he may roll it back to himself. Now is it not the case here one of a shebuth relating to the Temple in the country and yet no preventive measure has been enacted against the possibility that the scroll might fall down completely, and the man might then carry it? - Have we not explained this case as dealing with ' a threshold that was a karmelit in front of which passed a public domain ', so that, since its rolled up section was still in his hand, even the prohibition of shebuth does not exist.

He raised a further objection against him: The Paschal lamb may be lowered into the oven at dusk. Now is not the case here one of a shebuth relating to the Temple in the country and yet no preventive measure was enacted against the possibility that the man might stir up the coals? Thereupon he remained silent. When he came to R. Joseph and told him 'Thus said R. Safra to me,' the latter asked him: Why did you not answer him, 'The members of a [paschal lamb] party are careful' ? - And Abaye? - We only presume that the priests are careful, but we do not presume that the members of a [paschal lamb] party are also careful.

Raba explained: This represents the view of R. Eliezer who ruled that the preliminary requisites of a precept supersede the Sabbath, R. Eliezer however, agreeing that a change should be made as far as this is possible. ${ }^{2}$

\section{The controversy between R. Eleazar and R. Jose son of R. Hanina}

The Genizah fragment notes the controversy between the amoraim "R. Eleazar and R. Jose son of R. Hanina" (12-13 [see below, the line numbers in the reproduction]). This controversy has a parallel in Tractate Pesahim in the name of R. Eleazar and R. Jose son of R. Hanina with a few wording changes ${ }^{3}$ until the words "R. Eleazar" (17) in the fragment's version. The researchers are disagreed as to how the sugya was initially formed $(12-26){ }^{4}$

The phrase, further on in the fragment, "ve-idakh namei ha-katanei eim be-kli kan vekan assur" (16) interrupts the continuous understanding of the two possibilities for solving the contradiction between the Mishna here in Eruvin 103a ("hotkhin yabelet ba-mikdash") and the Mishna in Pesahim ("ve-hatikhat yabalto ein dohin et ha-

\footnotetext{
${ }^{2}$ EPSTEIN, 1938, p. 715-718.

${ }^{3}$ PESAHIM, 68b.

${ }^{4}$ AMINOAH, 2016, p. 958-959.
} 


\section{Arquivo Maaravi}

Shabbat") ${ }^{5}$ brought according to the two amoraim R. Eliezer (Eleazar) ${ }^{6}$ and R. Jose son of R. Hanina ("had amar... ve-had amar") (13). This is because the phrase "u-le-man de-meshani... amar lakh" (15) refers to a possible solution to the contradiction between the mishnayot cited by the second amora. Accordingly, the fragment continues with "ve-idakh namei ha-katanei eim be-kli kan ve-kan assur" (16), reverting to the possible solution to the contradiction cited by the first amora. Hence, the further phrase "veidakh hai de-katanei" (above the line)(16) reverts once again to the possible solution to the contradiction cited by the second amora. But in fact, this is not so, because the further words "ve-idakh hai de-katanei" (16) refer to the possible solution to the contradiction cited by the first amora, and therefore the phrase in the fragment "veidakh namei ha-katanei eim be-kli kan ve-kan assur" (16) interrupts the continuous understanding of the two possible solutions to the contradiction brought according to the two amoraim in the form of "ve-idakh... ve-idakh..." (i.e., clarifying the opinion of the first amora and then clarifying the opinion of the second amora and so on until reaching a resolution).

Furthermore, it is notable that this phrase in the fragment does not appear in the parallel sugya in Tractate Pesahim, ${ }^{7}$ and the sugya may not have been known as a single unit, both in Eruvin and in Pesahim, or perhaps these are two different sources. ${ }^{8}$

Further on in the fragment, after the word "de-Rabbanan" (17), the word "ve-idakh", which appears in all the versions, is missing. This word indicates an explanation (of the Mishna in Pesahim) according to the first amora. But in the fragment, it is missing, thus creating in the fragment a mixture of the methods of the second and first amora for explaining the Mishna in Pesahim. Moreover, the absence of the word "ve-idakh" creates a single continuity assumedly explaining the words of the Mishna in Pesahim only according to the second amora, generating a contradiction of his method. This is because in the absence of the word "ve-idakh" - it seems that the first part of the explanation of the Mishna in Pesahim (from "ve-idakh dumia... deherkevo" [16-17] until the word "de-Rabbanan" - [17]) states that the Mishna in Pesahim speaks of prohibitions ruled by the Rabbis, and the second part (from after the word "deRabbanan" [17] where the word "ve-idakh" should have appeared, until "tehumin [deorita]" - [17]) explains that prohibitions in the Mishna in Pesahim are Pentateuchal. This explanation creates a contradiction between the first part of the explanation and the second part - this is not possible. Not only because the absence of the word "veidakh" creates a contradiction in the method of the second amora, rather it also creates a contradiction in the explanation of the Mishna in Pesahim (65b). This is because it appears from the first part of this explanation (without the word "ve-idakh"),

\footnotetext{
${ }^{5}$ PESAHIM, 65b.

${ }^{6}$ Cf. ERUVIN, 10:12, 26c; PESAHiIM 6:1, $33 b$.

${ }^{7}$ PESAHIM, 68b.

8 ALBECK, 1969, p. 564.
} 


\section{Arquivo Maaravi}

Revista Digital de Estudos Judaicos da UFMG

ISSN: 1982-3053

according to the fragment's version, that "herkevo ve-havaato mi-hutz la-tehum" in the Mishna in Pesahim is a prohibition ruled by the rabbis, while from the second part of the explanation (from after the word "de-Rabbanan" (17), where the word "ve-idakh" should have appeared) it appears that "herkevo ve-hava'ato mi-hutz la-tehum" is a Pentateuchal prohibition, and this is a contradiction within the Mishna - which is not possible.

In addition, the absence of the word "ve-idakh" leaves the Mishna in Pesahim with no explanation according to the first amora, something that the sugya redactors try to avoid.

However when comparing the fragment's version to the version that $R$. Hananel has (to the extent that it is possible to separate his own words from the version cited in his words) the absence of the word "ve-idakh" may be because the fragment's version (of which part is absent) is like R. Hananel's version, who explains the first part mentioned above - as a problem ("ve-akshinan ve-ha hatikhat yabalto dumia [de-harkavato] vehavaato mi-hutz la-tehum katanei") and the second part - as a solution ("u-farkinan herkevo de-lo keR. Nathan" and so on), ${ }^{9}$ rather than as explanations of the different methods of the two amoraim mentioned above. Accordingly, the missing content in the fragment considerably affects any possibility of ascertaining the exact version of the fragment, was it like the versions presented above in the fragment or like that of $\mathrm{R}$. Hananel, or a mixture of versions - namely, some of the fragment's version was like the versions presented above and some like R. Hananel's. This uncertainty also affects the understanding of the sugya in light of the fragment's version.

\section{The give and take between R. Safra and Abaye}

Further on in the fragment there is a give and take that opens with the difficulty of "R. Safra le-Abaye ha-koreh ba-sefer" (20). R. Safra cites a Mishna, but the opening of the Mishna in the fragment "ha-koreh ba-sefer" differs from the version in the Mishna "haya kore ba-sefer. ${ }^{10}$ Further on, the fragment's version uses the terminology of a dialogue "amar leh ve-lav mi... okimna" (21-22). However, this phrase is missing in all the versions above (but is cited by R. Hananel ${ }^{11}$ ) and due to its absence, it seems that the redactors of the sugya answered R. Safra in Abaye's name with the phrase " ve-lo okimna". But according to the fragment's version "amar leh ve-lav mi... okimna" (2122) it was indeed Abaye who answered R. Safra explicitly. Therefore, the fragment's version, which notes this phrase, is notably clearer and well clarifies the dialogue between these two sages, more than the other versions.

The fragment's version has "eishatik... le-kameh deR. Yosef amar leh mai ta'ama lo tishnei leh" (24), and thus also in the version of MS Munich 95. However, the print

\footnotetext{
${ }^{9}$ R. HANANEL, Eruvin 103a.

${ }^{10}$ ERUVIN, 97b; SHABBAT, $5 b$.

${ }^{11}$ R. HANANEL, Eruvin 103b.
} 
version adds "le-kameh deR. Yosef amar leh hakhei amar li R. Safra amar leh mai ta'ama", and the MS Oxford 366 version adds "amar leh hakhei amar R. Safra vehakhei ahdari leh" (as does the version of Bologna, AS: Fr. ebr. 222). These additions may be late in time, as other sugyot ${ }^{12}$ that include the phrase " eishatik ki ata le-kameh" (two of four, where the person addressed is R. Yosef) do not state what the speaker said in the preceding dialogue (as here "hakhei amar li R. Safra") when addressing the Rabbi to whom he is now appealing with his problem. Therefore, the fragment's version may preserve a former and more accurate version, while the versions mentioned previously include later additions.

\section{Summary}

The missing content and the linguistic continuity in the fragment compared to other sources of the amoraic controversy between R. Eleazar and R. Jose son of R. Hanina make it hard to determine the precise version represented by the fragment. There are different options for understanding the fragment's version. The fragment's version may be identical to that of parallel sources or to R. Hananel's version or it may be a mixture of different versions cited by parallel sources and by R. Hananel's version. Hence, it is hard to determine the fragment's version and this has implications for understanding the sugya according to the fragment's version.

The give and take between the amoraim R. Safra and Abaye in the fragment's version may preserve a more ancient and accurate version. According to the fragment's version, the dialogue between these two sages is clearer than when compared to the versions mentioned above. Hence, the other versions may encompass later additions.

12 YEVAMOT, 110b; MAKKOT, 6a; ZEVAḤIM, 76a; ME`ILA, 3b. 


\section{Arquivo Maaravi}

Revista Digital de Estudos Judaicos da UFMG

ISSN: 1982-3053

Figure 1: The reproduction of the Genizah fragment: Cambridge U-L T-S F2 (2) 23

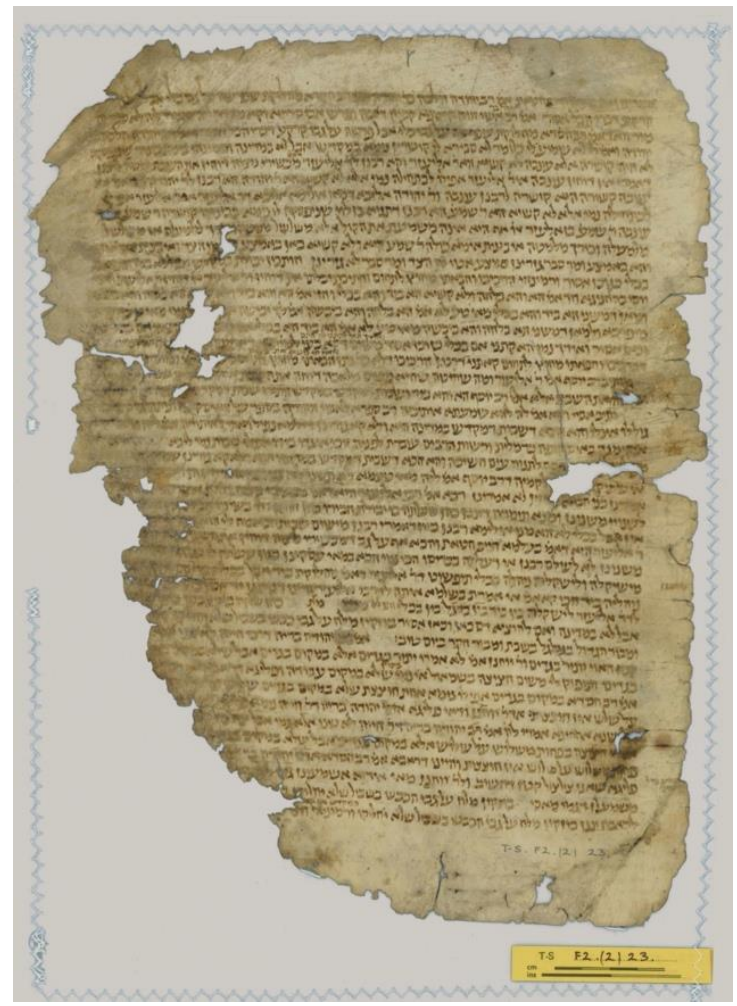

\section{References}

ALBECK, Chanoch. Introdudtion to the Talmud, Babli and Yerushalmi. Tel Aviv: Dvir, 1969.

AMINOAH, Noah. The Redaction of the Shabbat and Eruvin Tractates of the Babylonian Talmud. Tel Aviv: Tel Aviv University, 2016.

EPSTEIN, Isidore. The Babylonian Talmud, seder Mo 'ed, Erubin. London: Soncino, 1938.

Recebido em: 10/07/2020.

Aprovado em: 17/07/2020. 